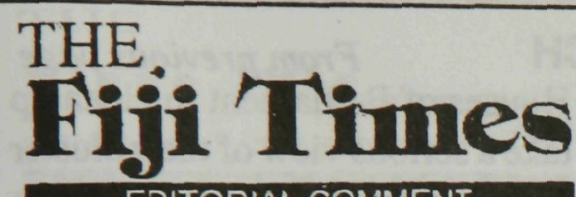

EDITORIAL COMMENT

\title{
Practise what you preach
}

WHEN the Senate sat for 20 minutes yesterday it cost the taxpayers $\$ 2400$. In those 20 minutes senators said a prayer, adopted the minutes of their last sitting and heard Senator Filipe Bole move the reading of five Bills. The House then adjourned for tea and until today. It can be taken for granted that the taxpayers also paid for morning tea.

That the people of this country must pay $\$ 2400$ for the Upper House to sit for 20 minutes is preposterous. This is more than half the amount that one-quarter of the households in this nation must survive on in a year.

A 1991 report showed that between 23 and 25 per cent of households live in poverty. These families earned less than $\$ 4316$ a year.

Yet our senators are content to spend more than half the amount that is considered the national poverty line for 20 minutes of sitting in a meeting.

Already this month members of the Lower House have racked up massive bills on overseas travel. It cost taxpayers $\$ 87,000$ to send three parliamentarians, a senator, the Speaker of the House and the secretary to Parliament to a meeting of very doubtful value in Cairo. Weeks later taxpayers paid around $\$ 15,000$ to send two cabinet ministers to talks in Geneva. The trips were not necessary.

Already the patience of the people has been tried. And now the senators appear to be pushing that patience to its very limit and beyond.

These are the same senators who must hold our parliamentarians accountable to the people. How can the Senate question uninhibited parliamentary spending if it cannot control its own finances?

Both Houses of Parliament have been scathing in their attacks on government enterprises which are not financially viable. They have called for leaner and meaner State enterprises like the Civil Aviation Authority.

At CAAF this will mean massive downsizing of staff in order to cut administrative costs. A large number of people will lose their jobs. They will receive redundancy payments but this will be of little comfort when our parliamentarians and senators appear to have little control of the national finances.

Continued overleaf 


\section{PRACTISE WHAT YOU PREACH}

From previous page

It is time for the members of both Houses of Parliament to clean up their act. They cannot expect anyone to take a serious view of their bluster on cost cutting and the need for improved productivity while they continue to squander other people's money while piously calling for greater efficiency.

Editorial in The Fiji Times on 30 September 1997.

\section{Hard-hitting editorials}

THE PUBLISHER and the editor of The Fiji Times appeared before the Fiji Senate Privileges Committee on 8 October 1997. Publisher Alan Robinson and editor Samisoni Kakaivalu were called to answer allegations that the newspaper breached parliamentary privilege by allegedly misrepresenting the Senate's proceedings.

After their appearance, the Privileges Committee resolved that one of its members, Senator Afzal Khan, and the lawyer for The Fiji Times, Richard Naidu, would meet to discuss further the concerns raised in the Senate.

The issue was over an editorial in The Fiji Times on September 30 (see previous page) criticising the Senate and parliamentary spending. On October 3, the Senate decided to refer The Fiji Times to the Privileges Committee over reports and the editorial saying that the Senate sitting on September 29 lasted not more than 20 minutes. The Fiji Times editorial, headlined PRACTISE WHAT YOU PREACH, questioned the cost to taxpayers of the 20 -minute sitting and said it was hard to take seriously calls by senators for others to cut costs and improve efficiency. Under Fiji's Parliamentary Privileges Act, the Privileges Committee could recommend that the Senate jail for up to two years those found to have breached parliamentary privilege.

However, the newspaper refused to apologise and when PJR went to press in November the issue had not been pursued any further. The Fiji Times followed up with a further editorial on October 2 (on the next page) criticising Senator Filipe Bole's condemnation of the foreign ownership of the newspaper. - IFEX and PMW 